\title{
Role of outer membrane c-type cytochromes MtrC and OmcA in Shewanella oneidensis MR-1 cell production, accumulation, and detachment during respiration on hematite
}

\author{
Authors: A.C. Mitchell, L. Peterson, C.L. Reardon, \\ D.E. Culley, M.R. Romine, \& G.G. Geesey
}

NOTICE: This is the peer reviewed version of the following article: Mitchell AC, Peterson L, Reardon CL, Reed SB, Culley DE, Romine MR, Geesey GG, "Role of outer membrane c-type cytochromes MtrC and OmcA in Shewanella oneidensis MR-1 cell production, accumulation, and detachment during respiration on hematite," Geobiology, July 2012 10(4):355-370, which has been published in final form http://dx.doi.org/10.1111/j.1472-4669.2012.00321.x. This article may be used for non-commercial purposes in accordance with Wiley Terms and Conditions for SelfArchiving."

Mitchell AC, Peterson L, Reardon CL, Reed SB, Culley DE, Romine MR, Geesey GG, "Role of outer membrane c-type cytochromes MtrC and OmcA in Shewanella oneidensis MR-1 cell production, accumulation, and detachment during respiration on hematite," Geobiology, July 2012 10(4):355-370 


\title{
Role of outer membrane c-type cytochromes MtrC and OmcA in Shewanella oneidensis MR-1 cell production, accumulation, and detachment during respiration on hematite
}

\author{
A. C. MITCHELL, $1, *$ L. PETERSON ${ }^{1}{ }^{C}$. L. REARDON $, 2,+{ }^{\dagger}$. B. \\ REED, ${ }^{2}$ D. E. CULLEY ${ }^{2}$ M. R. ROMINE ${ }^{2}$ AND G. G. GEESEY ${ }^{1}$ \\ 1
}

Department of Microbiology and Center for Biofilm Engineering, Montana State University, Bozeman, MT, USA 2

Microbiology Group, Pacific Northwest National Laboratory, Richland, WA, USA

\section{ABSTRACT}

\begin{abstract}
The iron-reducing bacterium Shewanella oneidensis MR-1 has the capacity to contribute to iron cycling over the long term by respiring on crystalline iron oxides such as hematite when poorly crystalline phases are depleted. The ability of outer membrane cytochromes OmcA and MtrC of MR-1 to bind to and transfer electrons to hema-tite has led to the suggestion that they function as terminal reductases when this mineral is used as a respiratory substrate. Differences in their redox behavior and hematite-binding properties, however, indicate that they play different roles in the electron transfer reaction. Here, we investigated how these differences in cytochrome behavior

with respect to hematite affected biofilm development when the mineral served as terminal electron acceptor (TEA). Upon attachment to hematite, cells of the wild-type (WT) strain as well as those of a DomcA mutant but not those of a DmtrC mutant replicated and accumulated on the mineral surface. The results indicate that $\mathrm{MtrC}$ but not $\mathrm{OmcA}$ is required for growth when this mineral serves as TEA. While an OmcA deficiency did not impede cell replication and accumulation on hematite prior to achievement of a maximum surface cell density comparable to that established by WT cells, OmcA was required for efficient electron transfer and cell attachment to hematite once maximum surface cell density was achieved. OmcA may therefore play a role in

overcoming barriers to electron transfer and cell attachment to hematite imposed by reductive dissolution of the mineral surface from cell respiration associated with achievement of high surface cell densities.
\end{abstract}

\section{INTRODUCTION}

The most common forms of microbiologically reducible iron

in surface and subsurface soils and sediments are amorphous

Fe(III) oxy-hydroxides, poorly crystalline iron oxides such as

ferrihydrite $\left(5 \mathrm{Fe}_{2} \mathrm{O} \approx 9 \mathrm{H}_{2} \mathrm{O}\right)$, and highly crystalline iron oxi-

des such as hematite $\left(\mathrm{a}-\mathrm{Fe}_{2} \mathrm{O}_{3}\right)$, magnetite $\left(\mathrm{Fe}_{3} \mathrm{O}_{4}\right)$, and goethite (a-FeOOH) (Cornell \& Schwertmann, 1996; Big-ham et al., 2002). While crystalline Fe(III) oxides may be more resistant to microbial reduction than amorphous

Fe(III) oxides, the former are often in greater abundance in shallow subsurface sediments that have not yet experienced significant microbial reduction. It has been suggested that microbial respiration on crystalline Fe(III) oxides may con-tribute to long-term $\mathrm{Fe}$ (II) generation and related impacts on subsurface aqueous and solid-phase geochemistry and support microbial growth in the subsurface when soluble and poorly crystalline Fe(III) become limiting (Roden \& Urrutia, 2002). The ability of many Fe-reducing bacteria to respire on crystalline forms of $\mathrm{Fe}(\mathrm{III})$ oxides indicates that these mineral phases play a role in their survival.

It now appears that proteins encoded by the mtrDEF-omcA-mtrCAB gene cluster in Shewanella oneidensis MR-1 play a central role in the transfer of electrons through the bac-terial cell envelope to extracellular solid-phase acceptors (Beli-aev et al., 2001; Hartshorne et al., 2007, 2009; Firer-Sherwood et al., 2008, 2011; Coursolle \& Gralnick, 2010; Clarke et al., 2011). Homologues of these genes occur in a range of bacterial phyla, indicating that the pathway has broad 
evolutionary and ecological relevance to electron transfer (Coursolle \& Gralnick, 2010). Common components of all solid-phase oxide reduction models are outer membrane multiheme c-type cytochromes (Myers \& Myers, 1997, 1998, 2003; Leang et al., 2003; Mehta et al., 2005). In the case of $S$. oneidensis MR-1, the transfer of electrons from the cell surface to the highly crystalline $\mathrm{Fe}$ (III) oxides involves the outer membrane decaheme $c$-type cytochromes OmcA and MtrC and soluble flavin molecules that function as extracellular electron shuttles (von Canstein et al., 2008; Marsili et al., 2008; Ross et al., 2009). MtrC and OmcA both appear to be able to bind to and exchange electrons with hematite (Xiong et al., 2006; Lower et al., 2007, 2009; Wigginton et al., 2007; Eggleston et al., 2008; Meitl et al., 2009). The two cytochromes, however, exhibit different electrochemical and physical interactions with hematite, suggesting that they have specific roles during the reduction reaction. OmcA has been proposed to play a greater role than MtrC in attachment of the cell to hematite (Xiong et al., 2006; Lower et al., 2007, 2008, 2009). The different roles played by OmcA and MtrC in cell binding and electron transfer to hematite may therefore be revealed through surface accumulation and detachment of cells during respiration on the mineral.

In this study, the wild-type (WT) strain and three outer membrane cytochrome in-frame deletion mutants of MR-1 $(\Delta m t r C, \Delta o m c A$, and $\Delta o m c A / \Delta m t r C)$ were compared in their ability to replicate and accumulate on as well as detach from natural specular hematite when this mineral served as an alternative terminal electron acceptor (TEA) under soluble TEA-limited conditions. When these cell activities were compared in the different strains, clear differences emerged for the roles of OmcA and MtrC during respiration on hematite.

\section{METHODS AND MATERIALS}

\section{Strains}

Shewanella oneidensis MR-1 (ATCC 700550) mutants were constructed by allele replacement using a two-step homologous recombination method (Marshall et al., 2006). The mutant strains were modified to constitutively express green fluorescent protein (GFP) by introduction of plasmid p519nGFP (ATCC 87453) (Matthysse et al., 1996) using methods described previously for expression in the WT strain (Gonzalez-Gil et al., 2005).

\section{Cultivation medium}

The different strains of MR-1 were cultivated in a defined medium ( $\mathrm{pH} 7.2$ ) consisting of the following (final concentrations): PIPES (piperazine- $\mathrm{N}, \mathrm{N}^{\prime}$-bis[ ethanesulfonic acid]) buffer $\left(0.907 \mathrm{~g} \mathrm{~L}^{-1}\right), \mathrm{NaCl}\left(10 \mathrm{mg} \mathrm{L}^{-1}\right), \mathrm{MgSO}_{4} \cdot 7 \mathrm{H}_{2} \mathrm{O}(61.43$ $\left.\mathrm{mg} \mathrm{L}^{-1}\right), \mathrm{MnSO}_{4} \cdot \mathrm{H}_{2} \mathrm{O}\left(5 \mathrm{mg} \mathrm{L}{ }^{-1}\right), \mathrm{CaCl}_{2} \cdot 2 \mathrm{H}_{2} \mathrm{O}\left(1 \mathrm{mg} \mathrm{L}{ }^{-1}\right)$, $\mathrm{NH}_{4} \mathrm{Cl}\left(594 \mathrm{mg} \mathrm{L}^{-1}\right), \mathrm{KCl}\left(9.7 \mathrm{mg} \mathrm{L}^{-1}\right), \mathrm{NaH}_{2} \mathrm{PO}_{4} \cdot \mathrm{H}_{2} \mathrm{O}$
(9.9 $\left.\mathrm{mg} \mathrm{L}^{-1}\right), \mathrm{Na}_{2} \mathrm{SeO}_{4} \cdot 10 \mathrm{H}_{2} \mathrm{O}\left(0.037 \mathrm{mg} \mathrm{L}^{-1}\right), \mathrm{CoCl} \cdot 6 \mathrm{H}_{2} \mathrm{O}$ $\left(1 \mathrm{mg} \mathrm{L}{ }^{-1}\right), \mathrm{ZnCl}_{2}\left(1.3 \mathrm{mg} \mathrm{L}^{-1}\right), \mathrm{CuSO}_{4}\left(0.06 \mathrm{mg} \mathrm{L}^{-1}\right)$, $\mathrm{Al}_{2}\left(\mathrm{SO}_{4}\right)_{3} \cdot 18 \mathrm{H}_{2} \mathrm{O} \quad\left(0.14 \mathrm{mg} \mathrm{L}^{-1}\right), \mathrm{H}_{3} \mathrm{BO}_{3} \quad\left(0.1 \mathrm{mg} \mathrm{L}^{-1}\right)$, $\mathrm{Na}_{2} \mathrm{MoO}_{4} \cdot \mathrm{H}_{2} \mathrm{O}\left(0.29 \mathrm{mg} \mathrm{L}^{-1}\right), \mathrm{NiCl}_{2} \cdot 6 \mathrm{H}_{2} \mathrm{O}\left(0.25 \mathrm{mg} \mathrm{L}^{-1}\right)$, $\mathrm{NaWO}_{4} \cdot 2 \mathrm{H}_{2} \mathrm{O}\left(0.25 \mathrm{mg} \mathrm{L}^{-1}\right)$, nitrilotriacetic acid (NTA-H) $\left(15 \mathrm{mg} \mathrm{L}^{-1}\right)$, folic acid $\left(0.02 \mathrm{mg} \mathrm{L}^{-1}\right)$, pyridoxine $\mathrm{HCl}$ $\left(0.1 \mathrm{mg} \mathrm{L}^{-1}\right)$, riboflavin, thiamine, nicotinic acid, $\mathrm{p}$-aminobenzoic acid, pantotheic acid, thioctic acid $\left(0.05 \mathrm{mg} \mathrm{L}^{-1}\right)$, vitamin B-12 (0.001 $\left.\mathrm{mg} \mathrm{L}^{-1}\right)$, L-arginine, L-serine, and L-glutamic acid $\left(20 \mathrm{mg} \mathrm{L}^{-1}\right)$. Kanamycin was added to a final concentration of $50 \mu \mathrm{g} \mathrm{mL}^{-1}$ to maintain selective pressure on cells of the different strains to retain the p519nGFP plasmid. Na-lactate (11.2 $\mathrm{g} \mathrm{L}^{-1}$ of $60 \% \mathrm{Na}$-lactate solution) served as the carbon source and electron donor. The defined medium was supplemented with Na-fumarate $\left(4.8 \mathrm{~g} \mathrm{~L}^{-1}\right)$ or hematite particles as TEA. Ascorbic acid ( $1.5 \mathrm{~mm}$ final concentration) was added to scavenge residual oxygen from the medium. Resazurin $(0.2 \%$ final concentration) was added to the medium of one series of experiments that utilized one hematite-containing and one silicon-containing AFC for each strain (Series 1) to confirm that the reduction potential was less than $-110 \mathrm{mV}$. As resazurin interfered with the ferrozine assay, it was withheld from a second series of replicate experiments comprised of one hematite-containing and one siliconcontaining AFC for each strain (Series 2) to assay soluble $\mathrm{Fe}(\mathrm{II})$ in the AFC effluent.

\section{Substratum preparation}

Specular hematite $\left(\boldsymbol{\alpha}-\mathrm{Fe}_{2} \mathrm{O}_{3}\right)$ (provided by Kevin Rosso at the Pacific Northwest National Laboratory, Richland, WA, USA) served as the crystalline solid-phase TEA in the experiments described later. The hematite was cleaved to produce flakes with freshly exposed surfaces of the $(001)$ crystal plane. The flakes were heated to $800{ }^{\circ} \mathrm{C}$ in a combustion oven for 8 h to removed any $\mathrm{Fe}(\mathrm{II})$ or amorphous $\mathrm{Fe}(\mathrm{III})$ oxy-hydroxides from the surface and stored in a sealed $\mathrm{N}_{2}$ atmosphere prior to use to avoid formation of $\mathrm{Fe}$ (III) oxy-hydroxides.

The surface of a silicon wafer was used to account for surface-associated cell behavior attributable to respiration on dissolved oxygen introduced to the AFCs during the short pulses of aerobic feed medium (see Bacterial enumeration section below) and to account for respiration on other soluble components in the AFC feed medium that may serve as a TEA under the conditions of the experiments. Fragments of a silicon wafer (Virginia Semiconductor Inc., Fredricksburg, VA) were cleaned for $1 \mathrm{~h}$ in a $70 \%$ aqueous ethanol solution, air-dried, and stored in a sealed $\mathrm{N}_{2}$ atmosphere prior to use.

\section{Preparation and operation of AFCs}

The silicon wafer and the 001 crystal face of a hematite flake were flush mounted to the base of the flow channel of separate but otherwise identical acid-washed Teflon AFCs using LR 
White embedding resin (Ted Pella, Inc., Redding, CA, USA). The AFCs were assembled, connected to an anaerobic reactor system, autoclave sterilized, and purged with nitrogen gas prior to inoculation as previously described (Gonzalez-Gil et al., 2005). In this configuration, the side of the wafer embedded in the resin had no opportunity to transfer electrons to oxygen so could not serve as a TEA for cells that had accumulated on the side of the wafer exposed to the aqueous phase in the flow channel. The exposed surface area of hematite in each AFC was determined by collecting a microscopic image of the entire surface using a digital camera mounted on the microscope and quantifying the area using IMAGE analysis software. The surfaces of the flow channel in each AFC were inoculated under continuous flow conditions (volumetric

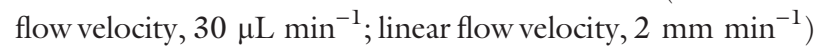
in a once-through manner using a multichannel peristaltic pump (Mannostat Corp., New York, NY, USA) and Norprene $^{\circledR}$ tubing to introduce an early logarithmic phase $\left(\mathrm{OD}_{600 \mathrm{~nm}}=0.015\right)$ batch culture using fumarate as TEA. The inoculated surface area, including the inlet and outlet PEEK tubing, was the same for both hematite- and siliconcontaining AFCs. The period of inoculation was adjusted to achieve a cell density on the hematite and silicon surfaces that provided 5-10\% surface coverage $\left(0.3-1.0 \times 10^{6} \mathrm{cells} \mathrm{cm}^{-2}\right)$. The feed to each AFC was then switched $\left(t_{0} \mathrm{~h}\right)$ to sterile anaerobic fumarate-free medium. The flow conditions for the duration of the experiment were the same as those employed during inoculation. Preliminary studies revealed that the oxygen concentration in the anaerobic AFC feed was below the threshold concentration $(<75 \mu \mathrm{M})$ required to activate GFP fluorescence in the cells attached to the silicon and hematite surfaces (Shaner et al., 2005). A study was therefore performed to determine the time required to activate the GFP in the cells by feeding aerobic medium through the AFC. The results indicated that replacement of the sterile anaerobic feed medium by a 5 -min pulse of flowing sterile aerobic medium immediately prior to enumeration on the hematite and silicon surfaces was adequate time to activate preformed GFP in the cells. Any cells present that did not fluoresce after 5 min were not included in the cell density determination. This reactor design and operation enabled real-time repetitive determination of surface cell density with minimal perturbation to the surface-associated cells. An experiment consisting of one hematite-containing and one silicon-containing AFC was performed in duplicate for each strain: one experiment containing resazurin in the feed medium (Series 1) and one experiment without resazurin in the feed medium (Series 2 ). All experiments were performed at $25{ }^{\circ} \mathrm{C}$.

\section{Bacterial enumeration}

The density of cells on the hematite and silicon surfaces was determined periodically in a noninvasive manner over the duration of an experiment by direct enumeration of GFP-fluo- rescing cells using epifluorescence microscopy (Gonzalez-Gil et al., 2005). The microscope was manually focused before enumerating the cells in each field of view where the surface was not parallel with the plane of focus. The number of cells in 10 or more randomly chosen fields of view was typically used to estimate the surface cell density at each enumeration period. The thickness of the biofilm on the hematite surface was determined using a calibrated vernier caliper on the fine focus knob of the microscope as previously described (Banks \& Bryers, 1991). Prior to enumeration of attached bacteria, the hematite surface was examined by reflected differential interference contrast microscopy (DIC) for evidence of inorganic precipitates as described previously (Neal et al., 2003).

The number of cells that detached from AFC surfaces was estimated by enumerating cell concentration in the effluent of each AFC collected at different times over the duration of an experiment. The volume of effluent collected for cell enumeration varied from $<1$ to $11 \mathrm{~mL}$ at the different sampling times of an experiment (Supplemental Information, Table S1). The differences were taken into account when calculating the instantaneous hematite-specific detachment rate $\delta$ (cells $\mathrm{cm}^{-2} \mathrm{~h}^{-1}$ ) (see equation 4 below). This range of sample volumes should not have had a noticeable effect on $\delta$. The tip of the effluent tubing was continuously submerged in a fixative solution (2X-strength filter-sterilized phosphate-buffered saline solution containing $1 \%$ glutaraldehyde) in acid-washed polyethylene vials to inhibit cell replication and preserve cell integrity during and between sampling periods. Samples of effluent collected in this manner at different times of an experiment were filtered through a polycarbonate membrane (0.2- $\mu \mathrm{m}$ pore size; Millipore Corp, Billerica, MA, USA), and the GFP-fluorescing cells trapped on the surface of the membrane enumerated by direct count epifluorescence microscopy. The number of cells in 10 or more randomly chosen fields of view of the membrane surface was used to estimate the number of detached cells in the effluent sample.

\section{Iron determination}

Total soluble Fe was measured in the AFC effluent in experiments performed with resazurin-containing feed medium (Series 1 experiments). A sample of the effluent was periodically collected in an acid-washed vial purged with $\mathrm{N}_{2}$ to ensure that any $\mathrm{Fe}(\mathrm{II})$ present did not become oxidized and precipitate from solution during collection. The sample was transferred to an anaerobic glove box and filtered to remove $\mathrm{Fe}$ associated with cells that had detached from AFC surfaces. The filtrate was acidified with trace metal grade $\mathrm{HNO}_{3}$ ( $1 \% \mathrm{w} / \mathrm{v}$ final concentration, $\mathrm{pH} \mathrm{l}$ ) and the total soluble $\mathrm{Fe}$ concentration quantified by measuring the response of the Fe-56 isotope on an Agilent model 7500ce inductively coupled plasma quadrupole mass spectrometer (ICP-MS). Interferences from $\mathrm{ArO}$ (argon oxide) ions were minimized by infusing helium gas at a flow rate of $4 \mathrm{~mL} \mathrm{~min}^{-1}$ into the 
octopole cell. The resulting detection limit for $\mathrm{Fe}$ was $<1 \mu \mathrm{g} \mathrm{L}^{-1}$. Analyte standards were prepared and used to calibrate the instrument over a range $\left(1-100 \mu \mathrm{g} \mathrm{L}^{-1}\right)$ of Fe concentrations. The element ion current $\left(I_{E_{i}}\right)$ data for the AFC effluent were converted to concentration $\left(\mathrm{C}_{i}\right)$ using the element standard solution current $\left(I_{E}\right)$ and the ICP-MS calibration equation

$$
C_{i}=I_{E_{i}}(\text { sample })\left[\frac{\text { element concentration }(\mathrm{std})}{I_{E}(\mathrm{std})}\right]
$$

The measured concentration $\left(C_{i}\right)$ thus represents the concentration of total dissolved $\mathrm{Fe}$ in the sample of AFC effluent. Trace quantities of iron in the sterile medium prior to introduction to the AFCs (blanks) were subtracted from that detected in the AFC effluent.

Soluble Fe(II) was determined in the AFC effluent of experiments performed with resazurin-free feed medium (Series 2 experiments) using the ferrozine assay as described previously (Gonzalez-Gil et al., 2005).

\section{Calculations}

The density of cells on the hematite surface resulting from growth through respiration of hematite $\mathrm{Fe}(\mathrm{III})$, referred to here as hematite-specific cell accumulation $A\left(\right.$ cells $\mathrm{cm}^{-2}$ ), was calculated as the difference between the mean cell density on the hematite surface $A_{b}$ and that on the silicon surface $A_{s}$ at sampling time $t$ according to

$$
A_{t}=A_{b_{t}}-A_{s_{t}}
$$

The change (increase) in the density of cells through $A$ between times $t$ and $t-1$ was calculated according to

$$
\Delta A_{(t-1) \rightarrow t}=\left(A_{b_{t}}-A_{b_{t-1}}\right)-\left(A_{s_{t}}-A_{s_{t-1}}\right)
$$

The instantaneous rate of cell detachment from all inoculated surfaces of the hematite- $\left(D_{h}\right.$, cells $\left.\mathrm{cm}^{-2} \mathrm{~h}^{-1}\right)$ or siliconcontaining AFCs $\left(D_{s}\right.$, cells $\left.\mathrm{cm}^{-2} \mathrm{~h}^{-1}\right)$ during the period of effluent sample collection was calculated according to

$$
D_{h, s}=\frac{\left(C_{h, s}\right)(V)}{(a)(t)}
$$

where $C_{h, s}$ is the cell concentration (cells $\mathrm{L}^{-1}$ ) in the effluent of the AFC containing the hematite or silicon substratum, $a$ is the inoculated surface area of the $\operatorname{AFC}\left(\mathrm{cm}^{2}\right)$, and $t$ is the time (h) over which a sample of the effluent was collected and subsequently diluted with buffered fixative solution to volume $V(\mathrm{~L})$. The rate of cell detachment from hematite during the period of effluent sample collection $t$, referred to here as instantaneous hematite-specific detachment rate $\delta$ (cells $\mathrm{cm}^{-2} \mathrm{~h}^{-1}$ ), was calculated according to

$$
\delta_{t}=\frac{D_{b_{t}}-D_{s_{t}}}{a}
$$

where $a$ is the area of the hematite surface. The number of cells that detach per unit area of hematite surface $\left(\right.$ cells $\mathrm{cm}^{-2}$ ) through $\delta$ between sampling periods $t$ and $t-1$ was calculated according to

$$
\int_{t-1}^{t} \delta \mathrm{d} x
$$

The number of cells produced per unit area of hematite surface per unit time $P\left(\right.$ cells $\left.\mathrm{cm}^{-2}\right)$ as a result of growth through respiration on hematite between sampling period $t$ and $t-1$ was calculated according to

$$
P_{(t-1) \rightarrow t}=\left(A_{t}-A_{t-1}\right)+\int_{t-1}^{t} \delta \mathrm{d} x
$$

The instantaneous rate of release of total soluble Fe from the hematite surface ( $\mathrm{nmol} \mathrm{Fe} \mathrm{cm}{ }^{-2} \mathrm{~h}^{-1}$ ) during the time of effluent sample collection was calculated according to

$$
\varepsilon=\frac{\left(\mathrm{nMFe}_{\text {total sol }}\right)(V)(t)}{a}
$$

where nм $F e_{\text {total sol }}$ is the concentration of total soluble $\mathrm{Fe}$ in effluent sample volume $V(\mathrm{~L})$ collected over time $t(b)$, and $a$ is the exposed area $\left(\mathrm{cm}^{2}\right)$ of the hematite surface from which the Fe was released. The quantity of total soluble Fe released from the hematite surface $\left(\mathrm{nmol} \mathrm{cm}{ }^{-2}\right)$ between sampling periods $t$ and $t-1$ was calculated according to

$$
\int_{t-1}^{t} \varepsilon \mathrm{d} x
$$

$\varepsilon$ was normalized to the density of cells that had accumulated through hematite-specific cell accumulation at time $t$ according to

$$
v_{t}=\frac{\varepsilon_{t}}{A_{t}}
$$

where $v$ is fmol $\mathrm{Fe} \mathrm{cm}^{-2} \mathrm{~h}^{-1}$ cell $^{-1}$ at sampling time $t$.

\section{Statistical analysis}

A two-tailed Student's $t$-test was used to evaluate differences between various data sets. Differences were considered significant if $P$-values were $\leq 0.05$.

\section{RESULTS}

\section{Growth of GFP-expressing WT and mutant strains on soluble TEAs}

The GFP-producing $\Delta o m c A, \Delta m t r C$, and $\Delta o m c A / \Delta m t r C$ mutants exhibited maximum growth rates $\left(\mu_{\max }=0.12,0.13\right.$ and $0.13 \mathrm{~h}^{-1}$, respectively) that were similar to that of the GFP-producing WT strain $\left(\mu_{\max }=0.15 \mathrm{~h}^{-1}\right)$ when cultivated anaerobically as suspended batch cultures in defined medium 
containing fumarate as TEA (Fig. S1). The results demonstrate that genetic manipulation to promote constitutive expression of GFP for visualizing cells on opaque surfaces had the same effect, if any, on the cytochrome-deficient mutants as on the WT strain when respiring anaerobically on fumarate. The results are also consistent with previous studies indicating that the outer membrane decaheme $c$-type cytochromes, OmcA and MtrC, are not required for respiration by cells using fumarate as TEA (Myers \& Myers, 2001).

\section{Production of OmcA and MtrC by GFP-expressing mutants}

Western immunoblotting of whole-cell extracts confirmed the presence of MtrC and OmcA in the GFP-producing WT strain, the absence of MtrC and presence of OmcA in the GFP-producing $\Delta m t r C$ mutant, the absence of OmcA and presence of MtrC in the GFP-producing $\Delta o m c A$ mutant, and the absence of both cytochromes in the GFP-producing $\Delta m t r C / \Delta o m c A$ double mutant strain when grown anaerobically as suspended batch cultures in defined medium containing fumarate or hematite as TEA (Fig. S2). Based on visual observation, the OmcA band of the $\Delta m t r C$ mutant and the MtrC band of the $\Delta o m c A$ mutant were of similar intensity as the corresponding band from the WT strain when equal amounts of whole-cell extract were applied to the gel. These results suggest that the absence of MtrC did not significantly affect the quantity of OmcA produced in the $\Delta m t r C$ mutant, and the absence of OmcA did not significantly affect the amount of MtrC produced in the $\Delta o m c A$ mutant.

\section{Accumulation of cells on hematite and silicon surfaces}

Cells of the WT and mutant strains were capable of attachment to both hematite and silicon surfaces under the flow conditions employed in the current study. As the purpose of the study was to compare the accumulation and detachment of mutant and WT strains following initial attachment after the media was switched to sterile anaerobic fumarate-free medium $\left(t_{0} \mathrm{~h}\right)$, no effort was made to assess their efficiency of initial attachment to these substrata. Except during the 5-min pulses with aerobic fumarate-free medium to activate GFP in cells immediately prior to the determination of cell density on the hematite and silicon surfaces, the resazurin in the anaerobic medium pumped through the hematite- and siliconcontaining AFCs remained colorless in the glass flow break just upstream of the AFC inlet and upon exiting the effluent tubing, indicating that the Eh remained below $-110 \mathrm{mV}$ under these conditions. The slight increase in the density of cells of all strains on the silicon surface over the duration of an experiment (Fig. 1A,C,E,G) suggested that the AFC feed medium contained a TEA that supported growth of WT and cytochrome-deficient cells on AFC surfaces that do not serve as a TEA as discussed below. The maximum cell density $\left(A_{s_{\max }}\right)$ established by the $\Delta o m c A, \Delta m t r C$, and $\Delta o m c A / \Delta m t r C$ mutants on the silicon surface was similar to that achieved by the WT strain in replicated $(n=2)$ experiments (Table 1 , Series 1 and 2). These results suggest that OmcA and MtrC deficiencies had no significant effect on the ability of cells to accumulate on surfaces of the AFC when using the TEA in the feed medium for growth.

Wild-type cells established a significantly higher $(P<$ $0.0001, n=5$ ) cell density on the hematite surface than on the silicon surface after $96 \mathrm{~h}$ of exposure to the sterile feed medium (Fig. 1A). A similar result was obtained when the experiment was repeated (Table 2, Series 2). This indicates that accumulation of cells on surfaces of the AFC that do not serve as a TEA was TEA-limited, while cells associated with the hematite surface were able to overcome this limitation by using hematite $\mathrm{Fe}(\mathrm{III})$ as an alternative TEA. The difference between the density of cells on the hematite and silicon surfaces therefore reflects hematite-specific cell accumulation $(A)$. Coverage of the hematite surface by WT cells increased from $8 \%$ at the end of the inoculation period $\left(t_{0}\right.$ h $)$ to $95 \%$ at the time of maximum hematite-specific cell accumulation $\left(A_{\max }, t_{175 \mathrm{~h}}\right)$ (Fig. 2A,B). There was no evidence of active movement of WT or cytochrome-deficient cells across the hematite or silicon surface during the periods of cell enumeration. The WT biofilm that formed on the hematite surface over this period never exceeded a few cell layers in thickness $(2-3 \mu \mathrm{m})$ based on epifluorescence microscopy. There was also no evidence of secondary mineral precipitation on the hematite surface over the duration of an experiment based on surface examination by reflected DIC microscopy.

Accumulation of cytochrome-deficient cells on the hematite surface differed from that of the WT strain. Upon exposure to flowing sterile anaerobic fumarate-free medium, the $\Delta o m c A$ mutant required less time $(12 \mathrm{~h})$ than the WT strain $(96 \mathrm{~h})$ to achieve a maximum cell density on the hematite surface $A_{h_{\max }}$ that was greater than $A_{s_{\max }}$ on the silicon surface (Fig. 1A,C). The same result (data not shown) was obtained when the experiment was repeated (i.e. a set of one hematitecontaining AFC and one silicon-containing AFC inoculated with the WT strain and another set inoculated with the $\Delta o m c A$ mutant exposed to flowing sterile anaerobic fumarate-free medium). The $\Delta o m c A$ mutant also exhibited a maximum rate of hematite-specific cell accumulation that was higher but more variable than that exhibited by the WT strain based on the results of two independently performed experiments (Table 1, Series 1 and 2 experiments). However, the maximum density achieved by cells of the $\Delta o m c A$ mutant on the hematite surface $\left(A_{h_{\max }}\right)$ as well as the maximum density achieved through hematite-specific cell accumulation $\left(A_{\max }\right)$ was similar to those established by the WT strain in two independently performed experiments (Table 1; Series 1 and Series 2). Unlike cells of the WT strain, which maintained a surface cell density close to $A_{\max }$ following the period of maximum rate of cell accumulation (Fig. 1A), the surface density 

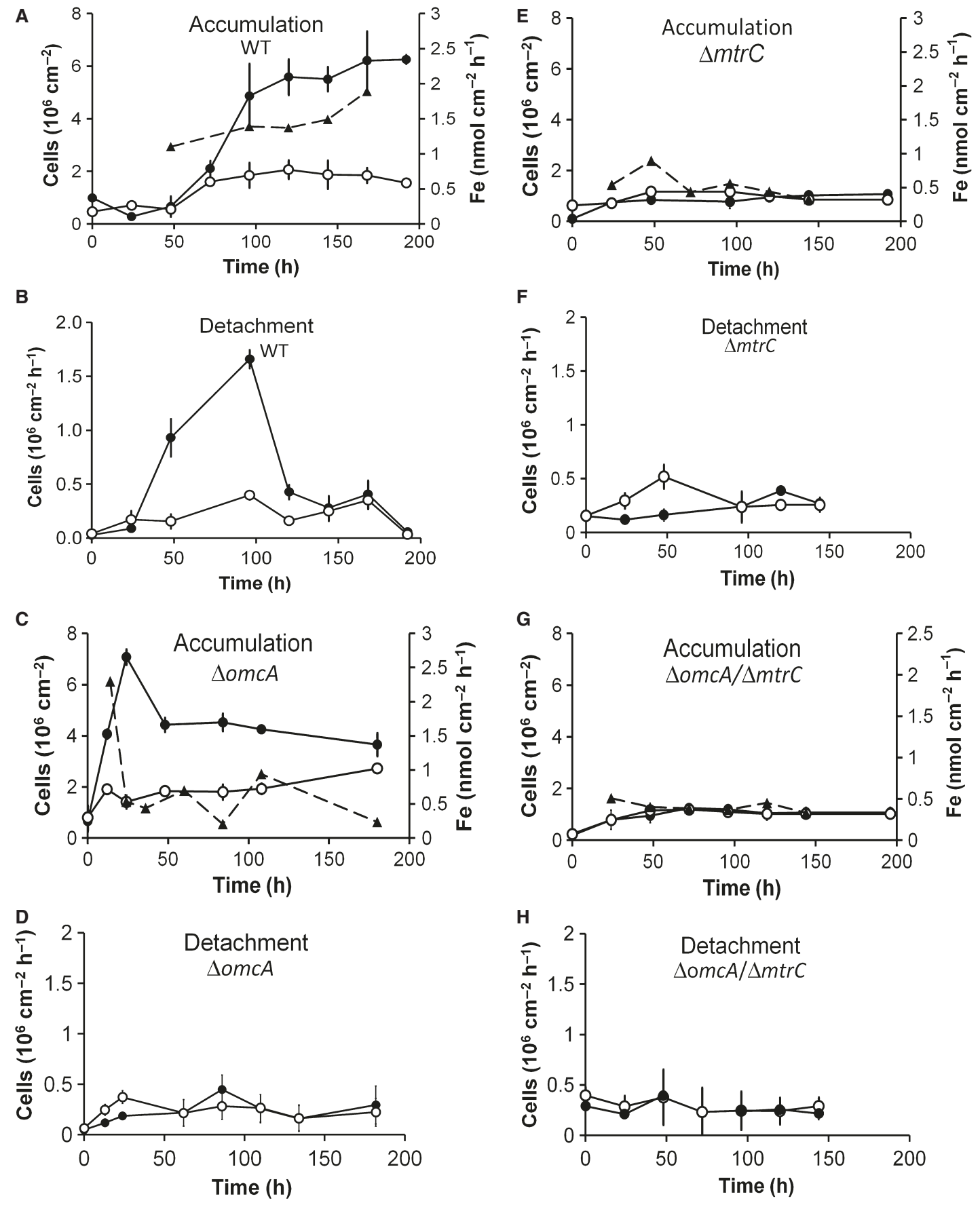

Fig. 1 Biofilm life cycle of different strains of MR-1 on hematite and silicon surfaces during exposure to anaerobic fumarate-free medium (Series 1 experiment). Accumulation of wild-type (WT) (A), $\Delta o m c A(C), \Delta m \operatorname{trC}(\mathrm{E})$, and $\Delta o m c A / \Delta m \operatorname{trC}(\mathrm{G})$ strains on hematite (solid circles) and silicon (open circles) surfaces and corresponding total soluble iron concentration (triangles) in the effluent of the hematite-containing AFC. Detachment of cells of WT (B), $\Delta$ omcA (D), $\Delta m t r C$ (F), and $\Delta$ omcA/ $\Delta m t r C$ $(\mathrm{H})$ strains from hematite (solid circles) and silicon (open circles) surfaces. Data points and associated error bars represent the mean \pm 1 standard deviation of cell counts from different fields of view across the hematite or silicon surface or on the membrane surface after filtration of a sample of the effluent from the AFC ( $n \geq 10$ ).

of cells of the $\Delta o m c A$ mutant attributable to hematite-specific cell accumulation ( $A$ ) decreased to $45 \%$ of $A_{\max }$ (Fig. 1C). By the end of the experiment, $A$ was only $16 \%$ of $A_{\max }$ (Table 1 , Series 1 experiment). A similar number of cells detached from the hematite surface after achieving $A_{\max }$ when the experiment was repeated, but in this case, the density of cells remaining on the hematite surface was not significantly different from that on the silicon surface by the end of the experiment. 
Table 1 Accumulation of cells on hematite and silicon surfaces

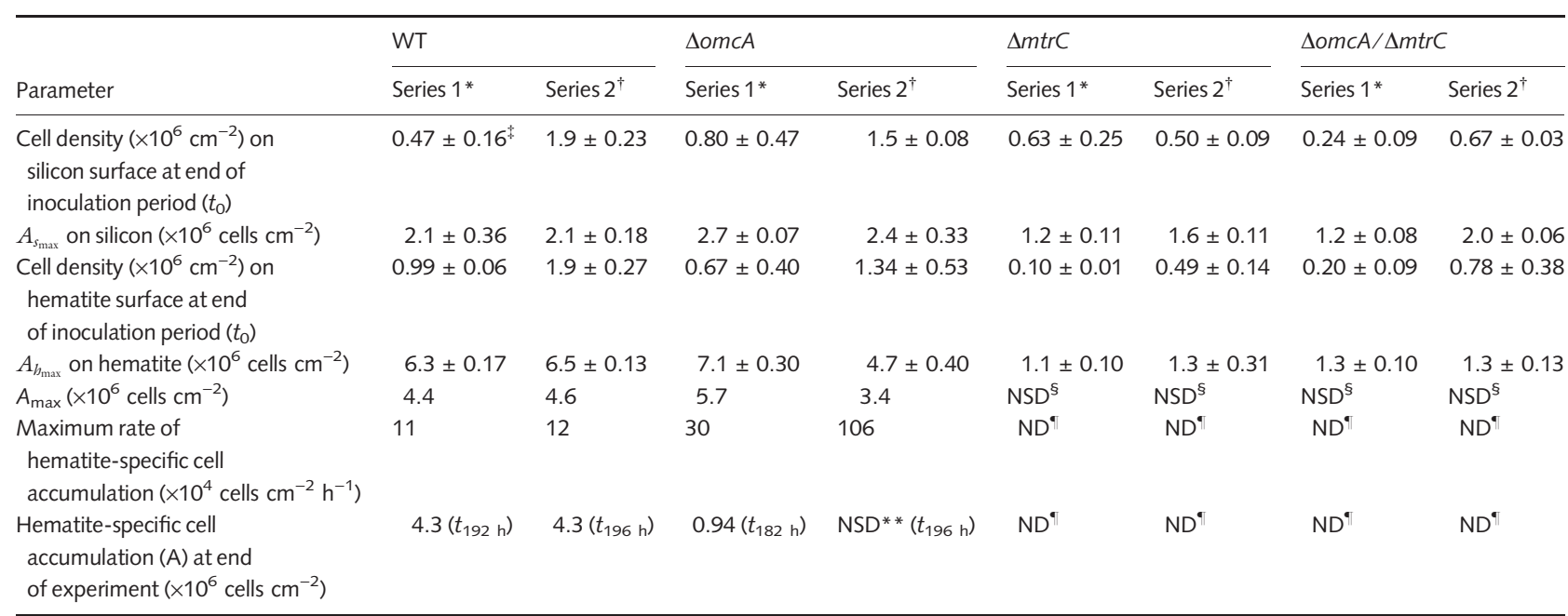

WT, wild-type.

* Series 1 refers to experiment in which one hematite- and one silicon-containing AFC for each strain were exposed to resazurin-containing feed medium here and in subsequent tables.

$\dagger$ Series 2 refers to experiment in which one hematite- and one silicon-containing AFC for each strain were exposed to resazurin-free feed medium here and in subsequent tables.

$\$ \pm$ here and elsewhere in the table refers to \pm 1 standard deviation around the mean where $n \geq 10$.

$\S$ No significant difference between cell density on hematite and silicon surfaces at any sampling time during exposure to sterile fumarate-free medium, $n \geq 10$.

-No hematite-specific cell accumulation.

* * No significant difference in cell density on hematite and silicon surface at end of experiment, $n \geq 10$.

This was likely a reflection of the lower $A_{\max }$ achieved in this experiment (Table 1, Series 2). Cells of the $\Delta m \operatorname{tr} C$ mutant and $\Delta o m c A / \Delta m t r C$ mutant never achieved a density on the hematite surface that was significantly greater than the density of cells on the silicon surface during exposure to flowing sterile fumarate-free medium (Fig. 1E,G), precluding calculation of a maximum rate of hematite-specific cell accumulation or $A_{\text {max }}$ for these mutants.

\section{Detachment of cells from AFC surfaces}

WT and cytochrome-deficient cells were recovered from the effluent of both the hematite- and silicon-containing AFCs during the time they were fed sterile anaerobic fumarate-free medium, indicating that cells had detached from the inoculated AFC surfaces. Virtually all cells occurred as singlets on the membrane filter at all sampling periods; cell aggregates were rarely observed. In one set of experiments (Series 1) involving one silicon-containing AFC for each strain, the number of cells of the different strains recovered from the effluent over a 134- to 144-h period of exposure to flowing sterile medium ranged from $2.5 \times 10^{8}$ to $3.8 \times 10^{8}$ cells, nearly two orders of magnitude greater than the number of cells that had accumulated on all inoculated surfaces of each AFC at the end of the inoculation period $\left(2.2 \times 10^{6}\right.$ to $7.2 \times 10^{6}$ cells) (Table 2 ). This calculation was based on the assumption that the cell density on all inoculated surfaces (Teflon AFC and PEEK tubing) was the same as that on the silicon surface. A similar result was obtained when the experiment was repeated (Series 2, data not shown). It is unlikely that the cells in the effluent replicated between the time of detachment and collection in the fixative-containing vials because the residence time of the flowing medium in the AFC and effluent tubing was only $7.3 \mathrm{~min}$. As the inoculated surfaces of the silicon-containing AFCs could not serve as a TEA, these data, like the accumulation results, suggest that the bulk of the detached cells were produced on the AFC surfaces using a substance dissolved in the feed medium as TEA. As the cell density of all strains on the silicon surface never exceeded $2.8 \times 10^{6}$ cells cm${ }^{-2}$ at the end of the experiment (Fig. 1A,C,E,G), detached cells represented $>99 \%$ of all cells produced on the surface over the duration of the experiment (Table 2). Furthermore, as the number of cells with OmcA and/or MtrC deficiencies that detached from surfaces of the silicon-containing AFCs was similar to the number of WT cells that detached from these surfaces (Table 2), the cytochromes did not appear to be required when using the TEA dissolved in the feed medium for growth.

The number of WT and cytochrome-deficient cells that detached from all surfaces of the hematite-containing AFC over the first 134-144 h of exposure to sterile medium was 1-2 orders of magnitude greater than the number of cells that were on all inoculated surfaces of the AFC at the end of the inoculation period (Table 2). Nearly three times more WT cells detached from the inoculated surfaces of the hematitecontaining AFC than from the surfaces of the silicon-contain- 
Table 2 Cell production and detachment during exposure to flowing sterile fumarate-free medium (Series 1 experiment)

\begin{tabular}{|c|c|c|c|c|}
\hline Parameter & WT & $\triangle o m c A$ & $\Delta m t r C$ & $\Delta o m c A / \Delta m t r C$ \\
\hline $\begin{array}{l}\text { No. of cells }\left(\times 10^{6}\right) \text { on all inoculated surfaces of } \\
\text { silicon-containing AFC at end of inoculation } \\
\text { period }\left(t_{0}\right)\end{array}$ & $4.2 \pm 1.4^{*}$ & $7.2 \pm 4.2^{*}$ & $5.7 \pm 2.3^{*}$ & $2.2 \pm 0.81^{*}$ \\
\hline $\begin{array}{l}\text { No. of cells }\left(\times 10^{8}\right) \text { that detached from all surfaces } \\
\text { in silicon-containing AFC }\end{array}$ & $2.5^{\dagger}$ & $3.1^{*}$ & $2.7^{\dagger}$ & $3.8^{\dagger}$ \\
\hline $\begin{array}{l}\text { No. of cells }\left(\times 10^{8}\right) \text { produced on all inoculated } \\
\text { surfaces of silicon-containing AFC }\end{array}$ & $2.5^{\dagger}$ & $3.1^{*}$ & $2.7^{\dagger}$ & $3.8^{\dagger}$ \\
\hline $\begin{array}{l}\text { Contribution of detached cells to cell production } \\
\text { on non-hematite AFC surfaces }\end{array}$ & $>99 \%$ & $>99 \%$ & $>99 \%$ & $>99 \%$ \\
\hline $\begin{array}{l}\text { No. of cells }\left(\times 10^{6}\right) \text { on all inoculated } \\
\text { surfaces of hematite-containing } \\
\text { AFC at end of inoculation period }\left(t_{0}\right)\end{array}$ & $4.5 \pm 0.14^{\S}$ & $7.1 \pm 4.2^{\S}$ & $5.3 \pm 0.25^{\S}$ & $2.1 \pm 0.09^{\S}$ \\
\hline $\begin{array}{l}\text { No. of cells }\left(\times 10^{8}\right) \text { that detached from all surfaces } \\
\text { in hematite-containing AFC }\end{array}$ & $7.1^{\dagger}$ & $2.9^{*}$ & $2.1^{\dagger}$ & $3.7^{\dagger}$ \\
\hline $\begin{array}{l}\text { Area-normalized hematite-specific } \\
\text { cell detachment (cells } \times 10^{8} \mathrm{~cm}^{-2} \text { ) }\end{array}$ & $9.4^{\circ}$ & $0.048 * *$ & $\mathrm{ND}^{\dagger \dagger}$ & $\mathrm{ND}^{\dagger \dagger}$ \\
\hline $\begin{array}{l}\text { Area-normalized cell detachment from } \\
\text { non-hematite surfaces (cells } \times 10^{8} \mathrm{~cm}^{-2} \text { ) }\end{array}$ & $0.042^{\circ}$ & $0.043 * *$ & ND林 & ND林 \\
\hline $\begin{array}{l}\text { No. of cells produced through hematite-specific } \\
\text { cell production (cells } \times 10^{8} \text { ) }\end{array}$ & 9.4 & 0.06 & $N D^{\S \S}$ & $N D^{\S \S}$ \\
\hline $\begin{array}{l}\text { Contribution of detached cells to } \\
\text { hematite-specific cell production }\end{array}$ & $>99 \%$ & $>99 \%$ & $N D^{\S \S}$ & $N D^{\S \S}$ \\
\hline
\end{tabular}

WT, wild-type.

*Assumed that the cell density on inoculated non-silicon surfaces of the AFC was the same as that on silicon surface. \pm refers to \pm 1 standard deviation around the mean $(n \geq 10)$

$\dagger t_{0} \rightarrow 144 \mathrm{~h}$.

$\ddagger t_{0} \rightarrow 134 \mathrm{~h}$.

$\S$ Calculated on the basis of the density of cells on the hematite and the silicon surfaces and the relative contribution of the hematite and non-hematite surfaces to the inoculated surface area of the AFC. It was assumed that the cell density on the non-hematite surfaces was the same as that on the silicon surface in the silicon-

containing AFC. \pm refers to \pm 1 standard deviation around the mean $n \geq 10$.

- $t_{0} \rightarrow 192 \mathrm{~h}$

${ }^{*} t_{24} \rightarrow 182 \mathrm{~h}$.

$\dagger$ No data because of no hematite-specific cell detachment.

+ Not determined

$\S \S$ No data because of no hematite-specific cell production.

ing AFC over this period of time (Table 2). By contrast, the number of cytochrome-deficient cells recovered in the effluent of the hematite-containing AFC was never greater than the number of cells that detached from all inoculated surfaces of the silicon-containing AFC over a similar period of time $\left(t_{0} \rightarrow 134\right.$ or $144 \mathrm{~h}$ ) (Fig. 1D,F,H; Table 2). Similar detachment results were obtained when the experiment was repeated (Series 2) with another single set of hematite- and siliconcontaining AFC for each of the four strains (data not shown). The detachment of cells of the $\Delta o m c A$ mutant from the hematite surface after achievement of $A_{\max }$ occurred too quickly to be detected in the effluent at the sampling frequency of the experiments (Fig. 1C,D).

The greater number of WT cells that detached from surfaces of the hematite-containing AFC than from surfaces of the silicon-containing AFC represents cells that had replicated on the hematite surface using hematite as TEA before detach- ment, referred to here as hematite-specific cell detachment $(\delta)$. Over the entire time, the AFCs were fed sterile fumaratefree medium $\left(t_{0} \rightarrow 192 \mathrm{~h}\right), \delta$ accounted for the release of $4.7 \times 10^{8}$ cells (Table 2 ). When normalized to surface area, the detachment of WT cells from the hematite surface was more than 200 times that from non-hematite surfaces in the AFC based on the number of cells recovered in the effluent of the silicon-containing AFC (Table 2). Although $\delta$ could not be determined from the number of cells recovered from the effluent of the hematite- and silicon-containing AFCs inoculated with the $\triangle o m c A$ mutant because they were not significantly different from one another, when based on the decrease in cell density on the hematite surface following achievement of $A_{\max }\left(t_{24} \rightarrow 182 \mathrm{~h}\right), \delta$ was only $2.4 \times 10^{6}$ cells or $4.8 \times 10^{6}$ cells cm$~^{-2}$. This is similar to the number of cells that detached from non-hematite surfaces of the AFC $\left(4.3 \times 10^{6}\right.$ cells cm$\left.{ }^{-2}\right)$ based on the number of cells recovered 

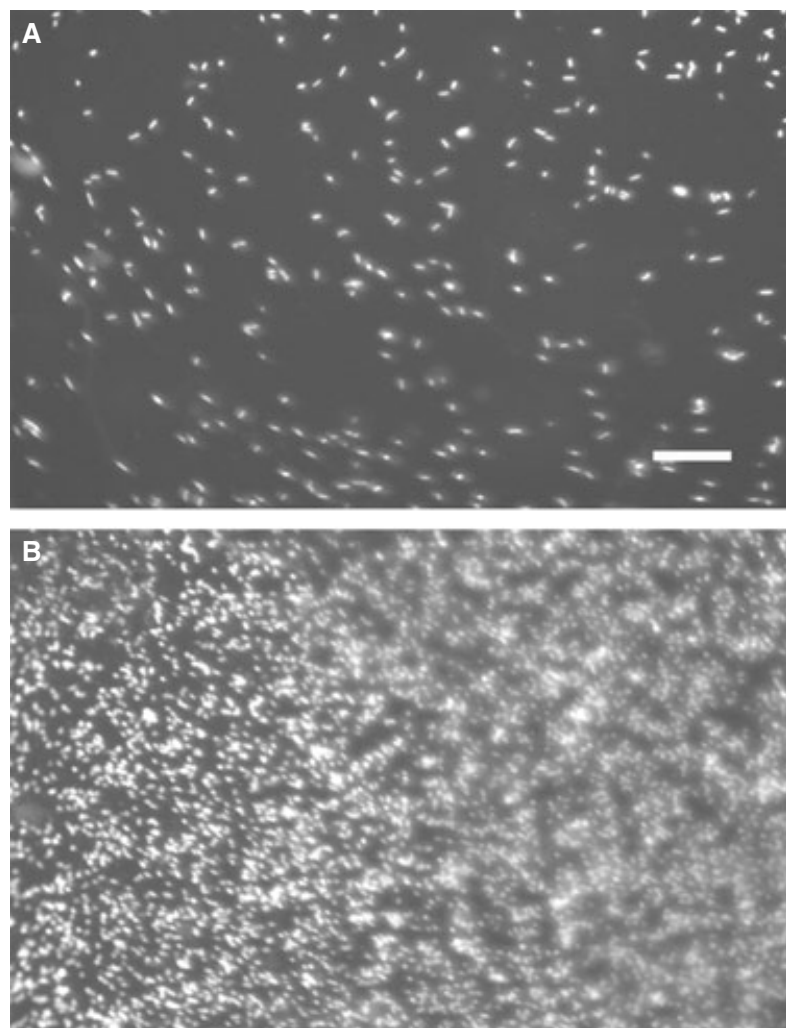

Fig. 2 Epifluorescent microscopic images of hematite surface colonized by wild-type MR-1 cells (A) immediately following the switch from the inoculum to sterile anaerobic fumarate-free medium and (B) after exposure to medium for $175 \mathrm{~h}$ in Series 1 experiment. Bar $=10 \mu \mathrm{m}$.

in the AFC effluent (Table 2). Consequently, hematitespecific cell production by the OmcA-deficient mutant over the duration of the 182-h experiment $\left(P_{\text {total }}\right)$ was $<1 \%$ of that of the WT strain over a comparable $(192 \mathrm{~h})$ period of time (Table 2). As observed for the silicon-containing AFC, $\delta$ accounted for $>99 \%$ of $P_{\text {total }}$ for both the WT strain and the $\triangle o m c A$ mutant (Table 3). As the $\triangle m+r C$ and the $\Delta$ omcA $\Delta m \operatorname{tr} C$ mutants exhibited neither hematite-specific cell accumulation nor hematite-specific cell detachment, those with an MtrC deficiency appeared to be incapable of hematite-specific cell production under the conditions of the study.

\section{Release of soluble Fe from the (001) crystal face of hematite colonized by WT and cytochrome-deficient strains}

Initial experiments revealed that the resazurin included in the sterile AFC feed medium to monitor redox conditions interfered with the quantification of $\mathrm{Fe}$ (II) in the AFC effluent using the ferrozine assay. As the medium contained no added $\mathrm{Fe}$, and preliminary studies showed no evidence of abiotic reduction of the (001) crystal face of hematite during preparation and after 40 days exposure to sterile anaerobic medium
(Fig. S3), total soluble Fe in the AFC effluent as determined by ICP-MS was used as a proxy for dissimilatory reduction of this crystal face of hematite by surface-associated cells (Series 1 experiments). The effluent of hematite-containing AFCs inoculated with the WT strain or the cytochrome-deficient mutants contained detectable amounts of total soluble $\mathrm{Fe}$ during the entire time the AFCs were fed sterile fumarate-free medium (Fig. 1A,C,E,G; Table 3). By contrast, the ferrozine assay was only able to detect soluble $\mathrm{Fe}$ (II) in resazurin-free effluent of AFCs inoculated with the WT strain and the $\Delta o m c A$ mutant and then only at times when $P>0$. No Fe(II) was detected in the effluent of AFCs inoculated with the $\Delta \mathrm{mtrC}$ or $\Delta$ omcA $\Delta \Delta \mathrm{mtrC}$ mutants using the ferrozine assay at any time during an experiment (Table 3 ).

When detectable, the concentration of soluble $\mathrm{Fe}(\mathrm{II})$ in the effluent of AFCs fed resazurin-free medium (Series 2 experiments) was often greater than the highest concentration of total soluble Fe measured in the effluent of the corresponding AFCs fed resazurin-containing medium (Series 1 experiments) (Table 3 ). This discrepancy likely reflected the inaccuracy of the ferrozine method at these $\mathrm{Fe}(\mathrm{II})$ concentrations, which were near the detection limit of the assay $(1 \mu \mathrm{M})$. The detection of $\mathrm{Fe}(\mathrm{II})$ in the AFC effluent, however, indicates that WT and OmcA-deficient cells reduced hematite during periods of cell production. As the concentration of $\mathrm{Fe}(\mathrm{II})$ in the effluent of the hematite-containing AFCs inoculated with the $\Delta m t r C$ and $\Delta o m c A / \Delta m t r C$ mutants was always below the detection limit of the ferrozine assay, it was not possible to establish whether the total soluble Fe released from the hematite surfaces colonized by these cytochromedeficient mutants occurred as $\mathrm{Fe}(\mathrm{II})$ and consequently whether these mutants were engaged in hematite reduction under these conditions.

The surface area-normalized instantaneous rate of release of total soluble Fe from the hematite surface $(\varepsilon)$ was often higher in the AFC inoculated with the WT strain than in the AFCs inoculated with the cytochrome-deficient mutants at times when there was no net hematite-specific cell production $(P=0)$, the only condition monitored in the study that all strains experienced (Table 3 ). However, when $\varepsilon$ was normalized to the density of cells established on the surface through hematite-specific cell accumulation $(A)$ to account for differences in surface cell density at each sampling time, the instantaneous release rate $(v)$ in the AFC inoculated with the $\Delta o m c A$ mutant was similar to that in the AFC inoculated with the WT strain at the respective times when $P=0$ (Table 3 ). Correspondingly, $v$ in the AFC inoculated with the $\triangle o m c A$ mutant was similar to that in the AFC inoculated with the WT strain at the respective time each strain achieved $P_{\max }$ (Table 3 ). However, $v$ was greater in the AFC containing the WT strain than in the AFC containing the $\Delta o m c A$ mutant at the time each strain achieved $A_{\max }$ (Table 3 ). Comparable $v$-values for the other two mutants could not be calculated because they did not exhibit hematite-specific cell accumulation. The mean $v$ in the 
Table 3 Soluble Fe released from the (001) crystal face of hematite colonized by WT and cytochrome-deficient mutants during exposure to flowing sterile anaerobic fumarate-free medium

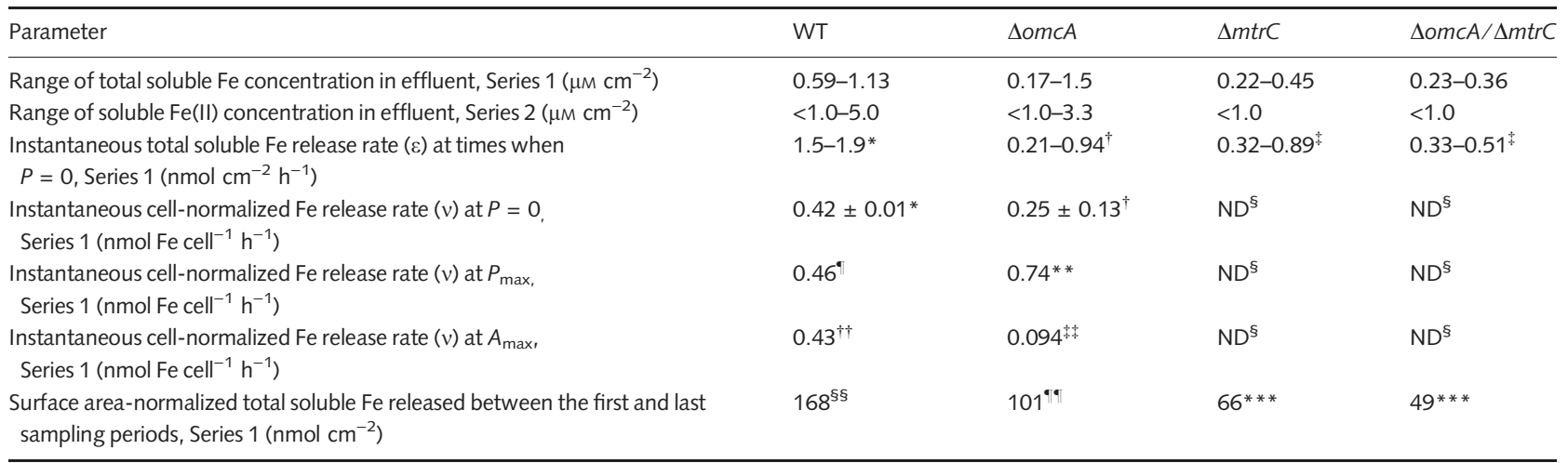

WT, wild-type.

${ }^{*} t_{144} \rightarrow 168$

$\dagger t_{60} \rightarrow 182 \mathrm{~h}$

$\ddagger t_{24} \rightarrow 144 \mathrm{~h}$

$\S N o$ hematite-specific cell accumulation.

- $t_{96} \mathrm{~h}$

${ }^{*}{ }^{*} t_{14} \mathrm{~h}$.

$\dagger \dagger t_{168} \mathrm{~h}$

$+t_{24} \mathrm{~h}$

$\S \S t_{48} \rightarrow 168 \mathrm{~h}$

थ $t_{14} \rightarrow 182 \mathrm{~h}$.

$* * t_{48} \rightarrow 144$

presence of the WT strain over the entire time when $P=0$ $\left(t_{144} \rightarrow 168 \mathrm{~h}\right)$ was nearly the same as that at $P_{\max }$ and $A_{\max }$. By contrast, the mean $v$ in the presence of the $\Delta o m c A$ mutant at $P=0$ after the net loss of OmcA-deficient cells from the surface $\left(t_{60} \rightarrow 182 \mathrm{~h}\right)$ was less than that at $P_{\max }$ but greater than that at $A_{\max }$ (Table 3$)$.

\section{DISCUSSION}

The production of WT and cytochrome-deficient cells on reactor surfaces that could not serve as a TEA indicated that the fumarate-free feed medium contained a substance that served as a growth-promoting TEA under the conditions of the study. The AFC feed medium contained riboflavin at a concentration $(133 \mathrm{nM})$ used in other MR-1 cultivation media as a vitamin supplement (Gorby et al., 2006). Cells of MR-1 have since been shown to synthesize this compound and use it to shuttle electrons to poorly crystalline $\mathrm{Fe}$ (III) oxide at concentrations as low as $1 \mu \mathrm{M}$ under batch cultivation conditions (von Canstein et al., 2008), and to a carbon electrode when present at a concentration of $250 \mathrm{~nm}$ (Marsili et al., 2008; Coursolle et al., 2010). Electron shuttles have also been reported to serve as sole TEA for cell growth (Lovley et al., 1996; Myers \& Myers, 2004). Mutants lacking MtrC or both MtrC and OmcA have been shown to be inhibited in their ability to reduce riboflavin when supplied as sole TEA and in their growth-dependent cell accumulation on a carbon electrode when riboflavin served as the electron shuttle (Coursolle et al., 2010). As the $\Delta m t r C$ and
$\Delta o m c A / \Delta m t r C$ mutants exhibited similar surface-associated cell production, accumulation, and detachment as the WT strain on the silicon surface, it appears that a substance other than riboflavin in the feed medium served as the growthpromoting TEA under these conditions. It also appears that the partial compensation in flavin reduction by $\mathrm{MtrF}$ and OmcA in the absence of MtrC (Coursolle \& Gralnick, 2010) had no detectable effect on these aspects of cell behavior under the conditions of the current study.

It is unlikely that dissolved oxygen accounted for the cell production observed in the silicon-containing AFCs. WT cells of MR-1 grown at low oxygen concentrations require longer periods of time to acclimate to higher oxygen concentrations than the 5-min periods of exposure to aerobic medium used in the present study to activate cellular GFP for cell visualization and enumeration (Elias et al., 2008). During exposure to anaerobic medium, the ascorbic acid present should have scavenged any oxygen that diffused through the reactor tubing from the surrounding atmosphere (Florence \& Farrar, 1973). As accumulation of all strains on the silicon surface was similar in experiments performed with and without resazurin in the feed medium (Series 1 and 2, respectively), it is unlikely that it served as the growthpromoting TEA. While identification of the substance is beyond the scope of the present study, the evidence that its utilization as a TEA was not influenced by deficiencies in these cytochromes enabled further investigation of the effects of these deficiencies on cell production, accumulation, and detachment when hematite served as alternative TEA. 
The greater production of cells of the WT strain and $\Delta o m c A$ mutant in the hematite-containing AFC than in the siliconcontaining AFC suggests that growth of these strains on non-hematite surfaces was limited by the TEA in the feed medium, a limitation that was relieved through the availability of hematite as an alternative TEA. As the hematite surface provided no relief from soluble TEA-limited growth in cells of the $\Delta m t r C$ and $\Delta o m c A / \Delta m t r C$ mutants, their inability to replicate using natural specular hematite as TEA appears to be specifically because of an MtrC deficiency. Thus, while previous studies have shown that cells with an MtrC deficiency are still capable of limited hematite reduction (Meitl et al., 2009), possibly through the compensatory activity of MtrF (Coursolle \& Gralnick, 2010), it appeared to be insufficient for cell replication under the conditions of the current study.

Comparison of the results of the present study with those of a previous report suggests that an OmcA or MtrC deficiency inhibits growth more when cells are attached to and respiring on the (001) crystal face of natural specular hematite than when in suspension respiring on soluble forms of ferric iron. Whereas the yield of suspended cells of an $\Delta o m c A$ mutant respiring on soluble $\mathrm{Fe}(\mathrm{III})$-NTA was $70 \%$ of the WT strain after $72 \mathrm{~h}$ (Borloo et al., 2007), hematite-specific cell production of the $\Delta o m c A$ mutant in the present study was only $35 \%$ and $<1 \%$ of that of the WT strain after 62 and $182 \mathrm{~h}$, respectively. Correspondingly, suspended cells of a $\Delta m t r C$ mutant respiring on soluble $\mathrm{Fe}(\mathrm{III})$-NTA or $\mathrm{Fe}(\mathrm{III})$-citrate over a 3 -day period achieved a cell density that was $\sim 12$ and $20 \%$ of WT cells, respectively (Borloo et al., 2007), whereas hematite-specific cell production by the $\Delta m t r C$ mutant in the present study remained undetectable over a 7 - to 8 -day period. A study of growth on hematite flakes in batch cultures with all crystal planes exposed would not be comparable to the growth observed on the (001) crystal face in the current study as earlier studies have shown that growth rates of the WT strain vary depending upon which crystal face serves as TEA (Neal et al., 2003).

Recent studies revealed that OmcA and MtrC together establish an interaction network with 16 proteins from the outer membrane, inner membrane, and cytosol (Zhang et al., 2008). In the absence of MtrC, the network is limited to interactions between OmcA and nine of the 16 proteins. We speculate that one or more protein interactions lost as a result of an MtrC deficiency are essential for achieving a rate of hematite reduction that supports cell growth: interactions that do not appear to be essential for the growth of suspended cells respiring on soluble forms of $\mathrm{Fe}(\mathrm{III})$. Systematic evaluation of strains with mutations in the genes encoding the proteins participating in these interactions should lead to identification of those functions responsible for deficiencies in growth when hematite serves as TEA.

Wild-type cells grown as suspended batch cultures with fumarate as TEA experienced a lag in growth on the hema- tite surface upon exposure to sterile fumarate-free feed medium. While detachment may have contributed to the delay in WT cell accumulation and biofilm development during the later part of the lag (Fig. 1A,B, $t_{24} \rightarrow 48 \mathrm{~h}$ ), the delay could not be attributed to cell detachment during the initial 24-h period of exposure to the fumarate-free medium. Lies et al. (2005) attributed a delay in the reduction of $\mathrm{Fe}(\mathrm{III})$ citrate by Shewanella putrefaciens strain CN32 to the presence of $\mathrm{Fe}(\mathrm{II})$, which promoted iron mineral precipitation on the cells. Initiation of growth coincided with disappearance of the precipitate. In the present study, there was no evidence of precipitation of a secondary mineral based on reflected DIC microscopic examination of the hematite surface during the lag period. WT cells of MR-1 respiring on low concentrations of $\mathrm{O}_{2}$ have been reported to experience a lag in growth upon exposure to higher concentrations of the TEA (Elias et al., 2008). The lag in this case was attributed to the time required for cells to sense the change in TEA concentration and express new proteins needed to respire under the new conditions. The lag displayed by WT cells in the present study may therefore have reflected the time required to up-regulate genes and synthesize proteins for respiration on solid-phase hematite that was not required for growth when fumarate served as TEA.

The absence of a detectable lag in hematite-specific cell production and biofilm formation by the $\Delta o m c A$ mutant upon initial exposure to sterile fumarate-free medium may reflect the inability of the mutant to sense the substitution of hematite for fumarate as a respiratory substrate. The interaction network established by OmcA and MtrC with the 16 other proteins is reduced to interactions between MtrC and only two of the 16 proteins in the absence of OmcA (Zhang et al., 2008). CydA, a putative cytochrome c ubiquinol oxidase (SO3826) missing from the network in the $\Delta o m c A$ mutant, may have a role in sensing and adapting to changes in TEA. A dual role has been demonstrated for cbb3 cytochrome $c$ oxidase that serves both as an electron acceptor and oxygen sensor in the photosynthetic bacterium Rhodobacter sphaero$i d e s(\mathrm{Oh}, 2006)$. An investigation of the role of CydA in these functions is however beyond the scope of the present study.

An inability of the OmcA-deficient mutant to sense the substitution of hematite for fumarate as a TEA may have caused the cells to utilize components of the electron transfer pathway used for fumarate reduction or an alternate pathway that did not require de novo protein synthesis for respiration on hematite. Other cytochrome mutants $(\Delta f c c A, \Delta$ nap, $\Delta i f c A l$, $\Delta m t r F, \Delta m t r D$, and $\Delta S O 3420)$ of MR-1 also exhibit higher rates of reduction of hydrous ferric oxides than the WT strain during the 24 to 50 -h period following the switch from respiration on fumarate (Bretschger et al., 2007; Schuetz et al., 2009). It has been suggested that deletion of specific cytochromes represents a roadblock to the normal flow of electrons to iron oxides resulting in redirection of electron flow through an alternative terminal reductase. An electron transfer 
network that functions in this manner is consistent with the overlapping redox potentials displayed by cytochromes such as CymA, STC, MtrA, MtrC, and OmcA (Firer-Sherwood et al., 2008). Thus, use of an electron transfer pathway that did not require de novo protein synthesis when fumarate was replaced by hematite as an available TEA may have enabled the $\Delta o m c A$ mutant to use the mineral as TEA, while avoiding the lag experienced by the WT strain.

A number of studies suggest a role for OmcA in attachment of MR-1 to various electrode and mineral surfaces including hematite (Xiong et al., 2006; Lower et al., 2007, 2008, 2009; Eggleston et al., 2008; Bouhenni et al., 2010). Coursolle et al. (2010) reported that a carbon electrode colonized by a $\Delta o m c A$ mutant contained only $70 \%$ of the protein of an electrode colonized by WT cells during a period of maximum current density (72-96 h). Correspondingly, the density of cells of the $\Delta o m c A$ mutant on the hematite surface achieved through growth by respiration on hematite $\mathrm{Fe}(\mathrm{III})$ was $68 \%$ of that of WT cells after 100-h exposure to sterile anaerobic fumarate-free medium. However, the lower mutant cell density on the hematite surface at $100 \mathrm{~h}$ occurred as a result of cell detachment after achievement of surface cell densities similar to those of the WT strain at $A_{\max }$. Thus, the attachment phenotype exhibited by the $\Delta o m c A$ mutant on hematite reflects the establishment of a lower more stable surface cell density through a net loss of cells from the surface after achievement of cell densities comparable to those of WT cells at $A_{\max }$.

Hematite surfaces colonized by the WT strain and $\Delta o m c A$ mutant exhibited their highest cell-normalized rate of release of total soluble Fe at the time each strain achieved its respective $P_{\max }$. The higher release rate in the presence of the mutant may be related to its greater rate of hematite-specific cell accumulation. The rate of release of total soluble Fe from the hematite surface at $P_{\max }$ likely approximated the rate of electron transfer from the cells to the surface because at these high release rates, the total soluble Fe detected in the effluent by ICP-MS could all be accounted for as soluble $\mathrm{Fe}$ (II) by the ferrozine assay. Thus, at $P_{\max }$ before achievement of $A_{\max }$, electron transfer efficiency does not appear to be impaired by an OmcA deficiency. By contrast, Coursolle et al. (2010) found the protein-normalized electron transfer rate between intact cells of a $\triangle o m c A$ mutant and a carbon electrode at maximum current density to be $74 \%$ of that which occurred in the presence of the WT strain. The effect of an OmcA deficiency on electron transfer efficiency may therefore depend on the nature of the solid-phase electron acceptor.

The OmcA deficiency did however impair electron transfer efficiency in the mutant upon achievement of a surface cell density comparable to that of the WT strain at $A_{\text {max }}$. Whereas the hematite surface containing WT cells experienced a cellnormalized Fe release rate at $A_{\max }$ that was $93 \%$ of the rate at $P_{\max }$ before achievement of $A_{\max }$, the release rate from the surface containing the mutant at $A_{\max }$ was only $13 \%$ of the rate prior to achievement of $A_{\max }$, and only $22 \%$ of the release rate in the presence of the WT strain at $A_{\max }$. As the soluble Fe(II) concentration was below detection by the ferrozine assay in the presence of the mutant at $A_{\max }$, electron transfer rates based on total soluble Fe should be interpreted with caution because other studies have reported the release of significant quantities of soluble $\mathrm{Fe}$ (III) into the aqueous phase during reduction of ferrihydrite by cells of MR-1 and $S$. putrefaciens CN32 (Taillefert et al., 2007; J. Fredrickson, personal communication). Nevertheless, the results suggest that while an OmcA deficiency does not impair electron transfer efficiency at $P_{\max }$ before achievement of $A_{\max }$, the deficiency does impair the efficiency once $A_{\max }$ is achieved. The attachment phenotype in OmcA-deficient cells may therefore be a response to the decreased efficiency of electron transfer to hematite at $A_{\text {max }}$.

If the attachment phenotype is expressed to alleviate impaired electron transfer in the $\Delta o m c A$ mutant at $A_{\text {max }}$, then one would predict a recovery of efficiency in those cells that remain on the surface following a reduction in surface cell density. Indeed, the average rate of release of total soluble Fe from the hematite surface during the period after the net loss of cells from the surface (60-182 h) was 2.7-fold higher than the rate at $A_{\max }$. This suggests that there is reducible Fe(III) on the hematite surface at $A_{\max }$, which is less accessible to OmcA-deficient cells at this cell density than at lower cell densities. Thus, access to this Fe(III) may control electron transfer efficiency. However, the cell-normalized rate of release of total soluble Fe from the hematite surface in the presence of the $\Delta o m c A$ mutant following the net loss of cells from the surface was still less than the rate at $P_{\max }$ prior to achievement of $A_{\max }$. This indicates that the attachment phenotype provides only partial relief from the electron transfer deficiency experienced by the $\Delta o m c A$ mutant at $A_{\max }$.

The lower cell-normalized Fe release rate from hematite in the presence of the $\Delta o m c A$ mutant following the net loss of cells from the surface when $P=0$ compared with that observed at $P_{\max }$ may be related to differences in the physiological state of the cells at these different stages of the biofilm life cycle. However, the release rate in the presence of the $\triangle o m c A$ mutant was still only $60 \%$ of the rate in the presence of the WT strain at the respective times in their biofilm life cycle when $P=0$. In other words, cells with an OmcA deficiency still function at lower electron transfer efficiency than those without the deficiency when in a physiological state that results in no net cell production. This was not the case, however, in the presence of WT cells where the average cellnormalized Fe release rate at $P=0$ was similar to the rate at the time of maximum cell production $(96 \mathrm{~h})$. Thus, the difference in electron transfer efficiency in the $\Delta o m c A$ mutant before achievement of $A_{\max }$ and after expression of the attachment phenotype cannot be attributable to physiological differences related to $P$.

The reductive dissolution of $\mathrm{Fe}$ (III) oxides by Fe-reducing bacteria has been shown to result in modifications to the oxide 
surface, which include $\mathrm{Fe}$ (III) solubilization (Taillefert et al., 2007), localized and non-localized pitting (Grantham et al., 1997; Rosso et al., 2003), the accumulation of Fe(II) (Roden \& Urrutia, 1999; Taillefert et al., 2007), and the precipitation of secondary minerals (Zachara et al., 1998; Benner et al., 2002; Hansel et al., 2005). While reflected DIC microscopy provided no evidence of secondary mineral formation during hematite-specific cell accumulation under the flow conditions used in the study, the dissolution of $\mathrm{Fe}$ (III), formation of pits, and accumulation of a thin passivating film of $\mathrm{Fe}(\mathrm{II})$ would not have been detected by this surface interrogation approach. We therefore postulate that OmcA plays a role in ameliorating one or more of these barriers to electron transfer to a hematite surface, which enables WT cells to maintain higher efficiencies at $A_{\max }$ than OmcA-deficient cells. Furthermore, the surface to which the remaining cells were exposed following expression of the attachment phenotype would not be expected to be restored to the pre- $A_{\max }$ condition and may explain why electron transfer efficiency in these cells did not return to the pre- $A_{\text {max }}$ level.

The pitting that results from the reductive dissolution of hematite by Shewanella increases surface roughness (Rosso et al., 2003). In the present study, surface roughness likely increased with hematite-specific cell accumulation. The ability of OmcA to exhibit structural flexibility to accommodate a variety of surface contours when binding to a surface (Lower et al., 2009; Johs et al., 2010), while playing only a minor direct role in the electron transfer reaction (Baron et al., 2009) has led to the suggestion that this cytochrome is better suited than others located at the cell surface to remain bound to a Fe-oxide surface as surface roughness increases (Coursolle \& Gralnick, 2010). The inability of the $\Delta o m c A$ mutant to remain bound to the hematite surface at densities at which the WT strain remains attached may therefore be a consequence of the former having a lower threshold for surface roughness than the latter. The ability of the $\Delta o m c A$ mutant to achieve for a short period of time a surface cell density similar to that of the WT strain at $A_{\max }$ indicates that other components on the surface of OmcA-deficient cells have a limited capacity to retain the cells at the surface under these conditions. Thus, the decrease in electron transfer efficiency and subsequent detachment of OmcA-deficient cells at $A_{\max }$ may arise from changes in the properties of the hematite that accompany the reductive dissolution reactions.

In the present study, detached cells accounted for virtually all WT and cytochrome-deficient cell production on nonnutritional surfaces when using a soluble substance in the overlying aqueous phase as TEA and virtually all WT and $55-100 \%$ of OmcA-deficient cell production when using hematite as an alternative TEA. This detachment behavior is consistent with previous studies in which the majority of cells growing as biofilms become detached during the biofilm life cycle (Baty et al., 2000; Stoodley et al., 2001; Neal et al., 2003; Bester et al., 2005; Rochex \& Lebeault, 2007).
The different hematite-specific detachment patterns exhibited by WT and OmcA-deficient cells may reflect differences in the energetic of the cells growing on the hematite surface. The extensive detachment of OmcA-deficient cells upon achievement of $A_{\max }$ when the efficiency of electron transfer to the surface was low is consistent with the massive detachment of WT cells from a non-nutrition glass surface in response to oxygen deprivation (Thormann et al., 2004). This massive detachment phenomenon was subsequently linked to a reduction in ATP concentration in the cells and evidence that maintenance of biofilm stability is an energydependent process (Saville et al., 2011). The fact that the WT strain never exhibited a net loss of cells from the hematite surface after achieving $A_{\max }$ and maintained an electron transfer efficiency at $A_{\max }$ when $P=0$ that was similar to that at $P_{\max }$ indicates that the cells were able to generate enough energy to maintain biofilm stability throughout the life cycle. Previous studies performed under conditions similar to those used here showed that production of WT cells of MR-1 was controlled by the structure of the Fe-oxide serving as TEA (Neal et al., 2003). Thus, hematite-specific WT cell production in the current study may also have been limited by the rate of electron transfer to the mineral surface even though the efficiency was adequate to maintain biofilm stability.

The higher rate of hematite-specific cell detachment by WT cells prior to and during the period of hematite-specific cell accumulation than after achievement of $A_{\max }$ may help maintain efficient electron transfer by the remaining surfaceassociated cells when the substratum serves as TEA. A similar pattern of detachment was displayed by a marine bacterium using a chitin surface as a carbon, nitrogen, and energy source (Baty et al., 2000). Thus, the pattern of detachment by WT MR-1 cells may depend on whether the surface serves as TEA. In sediments and saturated soils where growth occurs primarily on surfaces, a high detachment rate prior to achievement of high surface cell densities would minimize biofilm accumulation in the pore space, keeping it open for dispersion of progeny and allowing surface-associated cells access to nutrients in the flowing aqueous phase.

In summary, MtrC was required for hematite-specific cell production under soluble TEA-limiting condition, regardless of surface cell density. OmcA was required to retain cells that had accumulated on the hematite surface through hematitespecific cell production after achieving surface cell densities comparable to the $A_{\max }$ achieved by the WT strain. OmcA may play a role in overcoming physical barriers to electron transfer and cell attachment to hematite that develop during reductive dissolution of the mineral surface.

\section{ACKNOWLEDGMENTS}

This research was performed as part of an EMSL Scientific Grand Challenge project at the W.R. Wiley Environmental Molecular Science Laboratory, a national scientific user facility 
sponsored by the U.S. Department of Energy's (DOE) Office of Biological and Environmental Research Program and located at Pacific Northwest National Laboratory (PNNL). PNNL is operated for DOE by Battelle Memorial Institute under Contract DE-AC05-76RLO1830.

\section{REFERENCES}

Banks MK, Bryers JD (1991) Bacterial species dominance within a binary culture biofilm. Applied and Environmental Microbiology 57, 1974-1979.

Baron D, LaBelle E, Coursole D, Gralnick JA, Bond DR (2009) Electrochemical measurement of electron transfer kinetics by Shewanella oneidensis MR-1. Journal of Biological Chemistry 284, 2886528873.

Baty AM, Eastburn CC, Techkarnjanaruk S, Goodman AE, Geesey GG (2000) Spatial and temporal variations in chitinolytic gene expression and bacterial biomass production during chitin degradation. Applied and Environmental Microbiology 66, 3574-3585.

Beliaev AS, Saffarini DA, McLaughlin JL, Hunnicutt D (2001) MtrC, an outer membrane decahaem $c$ cytochrome required for metal reduction in Shewanella putrefaciens MR-1. Molecular Microbiology 39, 722-730.

Benner SG, Hansel CM, Wielinga BW, Barber TM, Fendorf S (2002) Reductive dissolution and biomineralization of iron hydroxide under dynamic flow conditions. Environmental Science and Technology 36, 1705-1711.

Bester E, Wolfaardt G, Joubert L, Garny K, Saftic S (2005) Planktonic-cell yield of a pseudomonad biofilm. Applied and Environmental Microbiology 71, 7792-7798.

Bigham JM, Fitzpatrick RW, Schulze DG (2002) Iron oxides. In Soil Mineralogy with Environmental Applications (eds Dixon JB, Schulze DG). Soil Science of America, Madison, WI, pp. 323-366.

Borloo J, Vergauwenm B, De Smet L, Brige A, Motte B, Devreese B, Van Beeumen J (2007) A kinetic approach to the dependence of dissimilatory metal reduction by Shewanella oneidensis MR-1 on the outer membrane cytochromes $c$ OmcA and OmcB. FEBS Journal 274, 3728-3738.

Bouhenni RA, Vora GJ, Biffinger JC, Shirodkar S, Brockman K, Ray R, Wu P, Johnson BJ, Biddle EM, Marshall MJ, Fitzgerald LA, Little BJ, Fredrickson JK, Beliaev AS, Ringeisen BR, Saffarini DA (2010) The role of Shewanella oneidensis MR-1 outer membrane surface structures in extracellular electron transfer. Electroanalysis 22, 856-864.

Bretschger O, Obraztsova A, Sturm CA, Chang IS, Gorby YA, Reed SB, Culley DE, Reardon CL, Barua S, Romine MF, Zhou J, Beliaev AS, Bouhenni R, Saffarini DA, Mansfeld F, Kim B-H, Fredrickson JK, Nealson KH (2007) Current production and metal oxide reduction by Shewanella oneidensis MR-1 wild type and mutants. Applied and Environmental Microbiology 73, 7003-7012.

Clarke TA, Edwards MJ, Gates AJ, Hall A, White GF, Bradley J, Reardon CL, Shi L, Beliaev AS, Marshall MJ, Wang Z, Watmough NJ, Fredrickson JK, Zachara JM, Butt JN, Richardson DJ (2011) Structure of a bacterial cell surface decaheme electron conduit. Proceedings of the National Academy of Sciences of the United States of America 108, 9384-9389.

Cornell RM, Schwertmann U (1996) The Iron Oxides: Structure, Properties, Reactions, Occurrence and Uses, Wiley-VCH Verlag GmbH \& Co, Weinheim, Germany.

Coursolle D, Gralnick JA (2010) Modularity of the Mtr respiratory pathway of Shewanella oneidensis MR-1. Molecular Microbiology 77, 995-1008.
Coursolle D, Baron DB, Bond DR, Gralnick JA (2010) The Mtr respiratory pathway is essential for reducing flavins and electrodes in Shewanella oneidensis. Journal of Bacteriology 192, 467-474.

Eggleston CM, Voros J, Shi L, Lower BH, Droubay TC, Colberg PJS (2008) Binding and direct electrochemistry of OmcA, an outermembrane cytochrome from an iron-reducing bacterium, with oxide electrodes: a candidate biofuel cell system. Inorganica Chimica Acta 361, 769-777.

Elias DA, Tollaksen SL, Kennedy DW, Mottaz HM, Clarke TA, Giometti CS, McLean JS, Hill EA, Pinchuk GE, Lipton MS, Fredrickson JK, Gorby YA (2008) The influence of cultivation methods on Shewanella oneidensis physiology and proteome expression. Archives of Microbiology 189, 313-324.

Firer-Sherwood MA, Pulcu GS, Elliott SJ (2008) Electrochemical interrogation of the Mtr cytochromes from Shewanella: opening a potential window. Journal of Biological and Inorganic Chemistry 13, 849-854.

Firer-Sherwood MA, Ando N, Drennan CL, Elliott SJ (2011) Solution-based structural analysis of the decaheme cytochrome MtrA, by small-angle $\mathrm{X}$-ray scattering and analytical ultracentrifugation. Journal of Physical Chemistry B 115, 11208-11214.

Florence TM, Farrar YJ (1973) Removal of oxygen from polarographic solutions with ascorbic-acid. Electroanalytical Chemistry and Interfacial Electrochemistry 41, 127-133.

Gonzalez-Gil G, Amonette JE, Romine MF, Gorby YA, Geesey GG (2005) Bioreduction of natural specular hematite under flow conditions. Geochimica et Cosmochimica Acta 69, 1145-1155.

Gorby YA, Yanina S, McLean JS, Rosso KM, Moyles D, Dohnalkova A, Beveridge TJ, Chang IS, Kim BH, Kim KS, Culley DE, Reed SB, Romine MF, Saffarini DA, Hill EA, Shi L, Elias DA, Kennedy DW, Pinchuk G, Watanabe K, Ishii S, Logan B, Nealson KH, Fredrickson JK (2006) Electrically conductive bacterial nanowires produced by Shewanella oneidensis strain MR-1 and other microorganisms. Proceedings of the National Academy of Sciences of the United States of America 103, 11358-11363.

Grantham MC, Dove PM, DiChristina TJ (1997) Microbially catalyzed dissolution of iron and aluminum oxyhydroxide mineral surface coatings. Geochimica et Cosmochimica. Acta 61, 44674477.

Hansel CM, Benner SG, Fendorf S (2005) Competing Fe(II)-induced mineralization pathways of ferrihydrite. Environmental Science and Technolology 39, 7147-7153.

Hartshorne RS, Jepson BN, Clarke TA, Field SJ, Fredrickson JK, Zachara JM, Shi L, Butt JN, Richardson DJ (2007) Characterization of Shewanella oneidensis MtrC: a cell-surface decaheme cytochrome involved in respiratory electron transport to extracellular electron acceptors. Journal of Biological Inorganic Chemistry 12, 1083-1094.

Hartshorne RS, Reardon CL, Ross D, Nuester J, Clarke TA, Gates AJ, Mills PC, Fredrickson JK, Zachara JM, Shi L, Beliaev AS, Marshall MJ, Tien M, Brantley S, Butt JN, Richardson DJ (2009) Characterization of an electron conduit between bacteria and the extracellular environment. Proceedings of the National Academy of Sciences of the United States of America 106, 22169-22174.

Johs A, Shi L, Droubay T, Ankner JF, Liang L (2010) Characterization of the decaheme $c$-type cytochrome OmcA in solution and on hematite surfaces by small angle X-ray scattering and neutron reflectometry. Biophysical Journal 98, 3035-3043.

Leang C, Coppi MV, Lovley DR (2003) OmcB, a $c$-type polyheme cytochrome, involved in $\mathrm{Fe}$ (III) reduction in Geobacter sulfurreducens. Journal of Bacteriology 185, 2096-2103.

Lies DP, Hernandez ME, Kappler A, Mielke RE, Gralnick JA, Newman DK (2005) Shewanella oneidensis MR-1 uses overlapping pathways for iron reduction at a distance and by direct contact under 
conditions relevant for biofilms. Applied and Environmental Microbiology 71, 4414-4426.

Lovley DR, Coates JD, Blunt-Harris EL, Phillips EJP, Woodward JC (1996) Humic substances as electron acceptors for microbial respiration. Nature 382, 445-448.

Lower BH, Shi L, Yongsunthon R, Droubay TC, McCready DE, Lower SK (2007) Specific bonds between an iron oxide surface and outer membrane cytochromes MtrC and OmcA from Shewanella oneidensis MR-1. Journal of Bacteriology 189, 49444952 .

Lower BH, Lins RD, Oestreicher Z, Straatsma TP, Hochella MF Jr (2008) In vitro evolution of a peptide with a hematite binding motif that may constitute a natural metal-oxide binding archetype. Environmental Science and Technology 42, 3821-3827.

Lower BH, Yongsunthon R, Shi L, Wildling L, Gruber HJ, Wigginton NS, Reardon CL, Pinchuk GE, Droubay TC, Boily J-F, Lower SK (2009) Antibody recognition force microscopy shows that outer membrane cytochromes OmcA and MtrC are expressed on the exterior surface of Shewanella oneidensis MR-1. Applied and Environmental Microbiology 75, 2931-2935.

Marshall MJ, Beliaev AS, Dohnalkova AC, Kennedy DW, Shi L, Wang ZM, Boyanov MI, Lai B, Kemner KM, McLean JS, Reed SB, Culley DE, Bailey VL, Simonson CJ, Saffarini DA, Romine MF, Zachara JM, Fredrickson JK (2006) $c$-Type cytochrome-dependent formation of U(IV) nanoparticles by Shewanella oneidensis. PLoS Biology 4, 1324-1333.

Marsili E, Baron DB, Shikhare ID, Coursolle D, Gralnick JA, Bond DR (2008) Shewanella secretes flavins that mediate extracellular electron transfer. Proceedings of the National Academy of Sciences of the United States of America 105, 3968-3973.

Matthysse AG, Stretton S, Dandie C, McClure NC, Goodman AE (1996) Construction of GFP vectors for use in gram-negative bacteria other than Escherichia coli. FEMS Microbiology Letters 145, 87-94.

Mehta T, Coppi MV, Childers SE, Lovley DR (2005) Outer membrane $c$-type cytochromes required for $\mathrm{Fe}(\mathrm{III})$ and $\mathrm{Mn}(\mathrm{IV})$ oxide reduction in Geobacter sulfurreducens. Applied and Environmental Microbiology 71, 8634-8641.

Meitl L, Eggleston CM, Colberg PJS, Khare N, Reardon CL, Shi L (2009) Electrochemical interaction of Shewanella oneidensis MR-1 and its outer membrane cytochrome OmcA and MtrC with hematite electrodes. Geochimica et Cosmochimica Acta 73, 5292-5307.

Myers CR, Myers JM (1997) Outer membrane cytochromes of Shewanella putrefaciens MR-1: spectral analysis, and purification of the 83-kDa $c$-type cytochrome. Biochimica et Biophysica Acta-Biomembranes 1326, 307-318.

Myers JM, Myers CR (1998) Isolation and sequence of $o m c A$, a gene encoding a decaheme outer membrane cytochrome $c$ of Shewanella putrefaciens MR-1, and detection of omc A homologs in other strains of S. putrefaciens. Biochimica et Biophysica Acta-Biomembranes $1373,237-251$.

Myers JM, Myers CR (2001) Role for outer membrane cytochromes OmcA and OmcB of Shewanella putrefaciens MR-1 in reduction of manganese dioxide. Applied and Environmental Microbiology 67, 260-269.

Myers CR, Myers JM (2003) Cell surface exposure of the outer membrane cytochromes of Shewanella oneidensis MR-1. Letters in Applied Microbiology 37, 254-258.

Myers CR, Myers JM (2004) Shewanella oneidensis MR-1 restores menaquinone synthesis to a menaquinone-negative mutant. Applied and Environmental Microbiology 70, 5415-5425.

Neal AL, Rosso KM, Geesey GG, Gorby YA, Little BJ (2003) Surface structure effects on direct reduction of iron oxides by Shewanella oneidensis. Geochimica et Cosmochimica Acta 67, 4489-4503.
Oh JI (2006) Effect of mutations of five conserved histidine residues in the catalytic subunit of the cbb3 cytochrome coxidase on its function. Journal of Microbiology 44, 284-292.

Rochex A, Lebeault J-M (2007) Effects of nutrients on biofilm formation and detachment of a Pseudomonas putida strain isolated from a paper machine. Water Research 41, 2885-2892.

Roden EE, Urrutia MM (1999) Ferrous iron removal promotes microbial reduction of crystalline iron(III) oxides. Environmental Science and Technology 33, 1847-1853.

Roden EE, Urrutia MM (2002) Influence of biogenic Fe(II) on bacterial crystalline $\mathrm{Fe}(\mathrm{III})$ oxide reduction. Geomicrobiology Journal $19,209-251$.

Ross DE, Brantley SL, Tien M (2009) Kinetic characterization of OmcA and MtrC, terminal reductases involved in respiratory electron transfer for dissimilatory iron reduction in Shewanella oneidensis MR-1. Applied and Environmental Microbiology 75, 52185226.

Rosso KM, Zachara JM, Fredrickson JK, Gorby YA, Smith SC (2003) Nonlocal bacterial electron transfer to hematite surfaces. Geochimica et Cosmochimica Acta 67, 1081-1087.

Saville RM, Rakshe S, Haagensen JJA, Shukla S, Spormann AM (2011) Energy-dependent stability of Shewanella oneidensis MR-1 biofilms. Journal of Bacteriology 193, 3257-3264.

Schuetz B, Schicklberger M, Kuermann J, Spormann AM, Gescher J (2009) Periplasmic electron transfer via $c$-type cytochromes MtrA and FccA of Shewanella oneidensis MR-1. Applied and Environmental Microbiology 75, 7789-7796.

Shaner NN, Steinbach PA, Tsien RY (2005) A guide to choosing fluorescent proteins. Nature Methods 2, 905-909.

Stoodley P, Wilson S, Hall-Stoodley L, Boyle JD, Lappin-Scott HM, Costerton JW (2001) Growth and detachment of cell clusters from mature mixed species biofilms. Applied and Environmental Microbiology 67, 5608-5613.

Taillefert M, Beckler JS, Carey E, Burns JL, Fennessey CM, DiChristina TJ (2007) Shewanella putrefaciens produces an Fe(III)-solubilizing organic ligand during anaerobic respiration on insoluble $\mathrm{Fe}(\mathrm{III})$ oxides. Journal of Inorganic Chemistry 101, 1760-1767.

Thormann KM, Saville RM, Shukla S, Pelletier DA, Spormann AM (2004) Initial phases of biofilm formation in Shewanella oneidensis MR-1. Journal of Bacteriology 186, 8096-8104.

von Canstein H, Ogawa J, Shimizu S, Lloyd JR (2008) Secretion of flavins by Shewanella species and their role in extracellular electron transfer. Applied and Environmental Microbiology 74, 615623.

Wigginton NS, Rosso KM, Lower BH, Shi L, Hochella MF (2007) Electron tunneling properties of outer-membrane decaheme cytochromes from Shewanella oneidensis. Geochimica et Cosmochimica Acta 71, 543-555

Xiong Y, Shi L, Chen B, Mayer MU, Lower BH, Londer Y, Bose S, Hochella MF, Fredrickson JK, Squier TC (2006) High-affinity binding and direct electron transfer to solid metals by the Shewanella oneidensis MR-1 outer membrane $c$-type cytochrome OmcA. Journal of the American Chemical Society 128, 1397813979.

Zachara JM, Fredrickson JK, Li S-M, Kennedy DW, Smith SC, Gassman PL (1998) Bacterial reduction of crystalline $\mathrm{Fe}^{3+}$ oxides in single phase suspensions and subsurface materials. American Mineralogist 83, 1426-1443.

Zhang H, Tang X, Munske GR, Zakharova N, Yang L, Zheng C, Wolff MA, Anderson GA, Shi L, Marshall MJ, Fredrickson JK, Bruce JE (2008) In vivo identification of the outer membrane protein OmcA-MtrC interaction network in Shewanella oneidensis MR-1 cells using novel hydrophobic chemical cross-linkers. Journal of Proteome Research 7, 1712-1720. 


\section{SUPPORTING INFORMATION}

Additional Supporting Information may be found in the online version of this article:

Fig. S1 Growth of WT and cytochrome-deficient strains of MR-1 under anaerobic conditions using fumarate as terminal electron acceptor.

Fig. S2 Protein analysis.
Fig. S3 Evaluation of stability of the hematite surface.

Table S1 Sampling times and volumes of effluent collected for determination of detached cells.

Please note: Wiley-Blackwell are not responsible for the content or functionality of any supporting materials supplied by the authors. Any queries (other than missing material) should be directed to the corresponding author for the article. 